Михајло П. Фејса

Филозофски факултет

Универзитета у Новом Саду
УДК 811.161.2(497.11)'367.625

DOI: 10.19090/gff.2017.1.271-287

Прегледни научни рад

\title{
ВИДСКИ ПАРОВИ У РУСИНСКОМ ЈЕЗИКУ
}

У русинистици се глаголском виду, а посебно видским паровима поклањала веома мала пажња. Ту чињеницу аутор потврђује освртом на приступе видским паровима у русинским граматикама (Хавријила Костељника, 1923; Николе Н. Кочиша, 1977; Јулијана Рамача, 2002). У раду је састављена листа од 255 видска пара, која у суштини представљају најчешће видске парове русинског језика. У централном делу рада су анализирани издвојени парови.

Кључне речи: русински језик, глаголски вид, видски парови, префиксација, суфиксација, глаголи кретања.

\section{УВОД}

Трагање за суштином категорије глаголског вида слависте је понекад доводило до дијаметрално супротних становишта. Настојећи да сумира погледе слависта В. В. Виноградов издваја три основне теорије (Vinogradov, 1972: 391-392). Прва се базира на становишту Ф. Миклошича који поделу на свршени и несвршени вид у руском глаголском систему тумачи као расцеп проузрокован, с једне стране завршеношћу радње, а с друге стране трајањем радње. Ова се подела на свршени и несвршени вид до данас задржала у граматикама и уџбеницима словенских језика, што се односи и на граматике и уџбенике русинског језика. Творац друге теорије је А. Х. Востоков. Он вид сагледава као израз етапа, тј. свршени вид по њему означава почетак и крај ситуације, а несвршени вид означава средину ситуације. Трећа, пунктуална теорија, базира се на учењима прво К. Бругмана и В. Делбрика, а затим Ф. Сосира и А. Мејеа. Творци ове теорије сматрају да свршени вид преноси ситуацију као нетрајну, тачковиту, пунктуалну, док несвршени вид преноси ситуацију као трајну, линеарну. Сам Виноградов је своје виђење семантике свршеног вида базирао на појму граница радње. Глаголи свршеног вида, по

\footnotetext{
*fejsam@gmail.com

** Рад је настао као резултат пројеката бр. 187002 и 187017, које финансира Министарство просвете, науке и технолошког развоја Републике Србије.
} 
њему, обележавају радњу која достиже свој циљ, своју границу, ограничавајући и уклањајући представу о трајању радње.

Почетком седамдесетих година Н. С. Авилова такође сагледава учења аспектолога-слависта и своди их на два (Avilova, 1976: 21-22). По првом, свршени вид преноси ситуацију изражену глаголом као да је целовита и монолитна; ово учење, по ауторки, произилази из пунктуалне теорије. По другом, свршени вид преноси достизање унутрашње апстрактне границе, односно циља одређене ситуације, по чијем се достигнућу ситуација исцрпљује и престаје. У овом раду ми подржавамо прво учење, првенствено због тога што је друго базирано на одређеном типу глаголске ситуације. О целини као о основном обележју свршеног вида говори и И. В. Исаченко: „Глаголима свршеног вида сагледавамо радњу споља и видимо је као целину, при чему су фазе почетак, средина и крај сведене на једну фазу, а глаголима несвршеног вида радња се сагледава као процес када радњу видимо изнутра, из средине, растворену, у ходу њеног остваривања, региструјући почетак, средину или крај" (Isačenko, 1960: 132-133). Посебну пажњу заслужује анализа А. В. Бондарка (Bondarko, 1971a: 11-12) која је резултирала закључцима да свршени вид постојано карактерише, с једне стране [+ целовитост], а с друге стране [- процесуалност]; несвршени вид, с једне стране карактерише [- целовитост], а с друге стране [+ процесуалност]. На том становишту је и Бернард Комри који основну опозицију категорије глаголског вида своди на сагледавање ситуација споља - изнутра, односно на опозицију целовитост - структура (Comrie, 1991: 30).

У Граматици бачко-русинског говора, првој граматици русинског језика Хавријил Костељник дели глаголе на несвршене и свршене, напомињући да је подела установљена с обзиром на трајање (подвукао Х. К.) радње, настајање итд. (Kostel’nik, 1975: 273). Видске парове Костељник не помиње.

С обзиром да је Никола Н. Кочиш нагласио да и глаголи русинског језика као и глаголи словенских језика имају особину да својим обликом указују на трајање радње или стања (Кос̌iš, 1978: 71) можемо рећи да се Кочиш у третирању аспекта надовезује на гледиште Костељника. Отуда и деоба глагола на: 1. имперфективне (несвршене, трајне) нпр. писаи, иедзиu, пиц и 2. перфективне (свршене, краткотрајне) нпр. написаи, щеднуи, випиц (срп. писати - написати, седети - сести, пити - испити). Кочиш закључује да основни, неизведени имперфективни и перфективни глаголи ступају у везу са префиксом па у том случају основни имперфективни глаголи постају перфективни (нпр. глагол патриц - препатрuц, допатрuи, напатриц ие, 
розпатриц, попатриц итд.) а основни перфективни глаголи остају перфективни (нпр. скочиц - прескочиц, доскочии, вискочиц, одскочиц, поскочиц, прескочиц итд.) (Кос̌іš, 1978: 77-78). Уз то, он разликује и секундарни глаголски вид којег чине имперфектизовани и перфектизовани глаголи (ibid.: 71-72), али никакву разлику, с једне стране, између перфективних и перфектизованих глагола и, с друге стране, између имперфективних и имперфектизованих глагола Кочиш не истиче. „Парове глагола" помиње само на једном месту и то у следећем параграфу своје граматике: „У нашем говору имамо парове глагола после творбе, на пример: учиц - научиц, волац - доволац, примушиц - примушовац, шеднуц - шедац, спушии ше - спущьовац ше, витац - привитац, чувац - зачувац, любиц полюбиц" (Кос̌iš, 1977: 96). Видски парови су занемарени и у Кочишевом „Правописном речнику русинског језика” (Кос̌iš, 1971) док им је у новом Правописном речнику (Fejsa, 2017) посвећена значајна пажња.

Јулијан Рамач је у трећој Граматици русинског језика видску проблематику сагледао много шире од Кочиша. Што се тиче видских парова Рамач им посвећује једно потпоглавље (Ramač, 2002: 115-116) у коме издваја 4 типа видских парова: 1. префиксне видске парове (нпр. писац - написац, подписаџ, преписаџ, записаџ, дописац, приписаџ, виписац, уписац, списац, одnисаи итд.); 2. суфиксне видске парове, које разликује према суфиксима инфинитивне основе (нпр. -а-/-ну-: лєгац - лєгнуц, шедац - шеднуц, сцекац сцекнуц итд.); 3. парове са превојем у основи (нпр. споминац - спомнуи, запинац - запнуи, вицинац - витнуц итд.); 4. парове са суплетивним основама (класи - положиц, брац - вжац, гуториц - повеси, бац ше - злєкнуи ше, глєдач - найси).

Рамач уочава и да су неки глаголи једновидски. Тако нпр. глагол несвршеног вида справовац ше нема пар свршеног вида, а глаголи свршеног вида поспац, виспац ше, наробиц ше, пошедзич немају парове несвршеног вида.

Рамач посвећује пажњу и двовидским глаголима. Тако нпр. поред видзиц и чуи, као двовидске, он наводи и глаголе буц, гуториц, познач и винчовац, као и неколико глагола страног порекла: информовац, бетоновац, асфалтовац и телефоновац. Пошто је видски модалитет двовидских глагола могуће одредити само у контексту, Рамач наводи пример глагола информоваи који је у реченици Пойдзем на схадзку, та вас наютре о шицким информуєм свршеног вида јер га је могуће заменити са дам вам информацию (срп. „даћу вам информацију"), а у реченици Бул сом на схадзки, та вас тераз информуєм несвршеног вида јер га је могуће заменити са тераз вам давам 
информацию (срп. „сада вам дајем информацију”) (ibid.: 115). Рамач примећује и да неки од двовидских глагола имају посебне облике за свршени вид: поинформовац, вибетоновац, виасфалтовац.

Већ смо истакли да се у овом раду под категоријом глаголског вида подразумева могућност сагледавања ситуација целовито (тотивно) и нецеловито, у структури (атотивно). Категорија вида се, према томе, најсажетије дефинише као граматикализовани израз сагледавања реализације глаголске ситуације као тотивне или атотивне (Fejsa, 2005: 126; Fejsa, 2005b).

За одређивање видског модалитета водили смо се синтаксичким тестом. Уколико глаголи у оквиру конструкције Вø (традиционално познате као презент; Fejsa, 2009) реализације глаголских ситуација локализују у сегмент садашњост, онда су атотивни (АТОТВø; нпр. пищем, читам, препатрам; срп. "пишем", "читам", "прегледавам"), а уколико реализације глаголских ситуација локализују у сегмент будућност, онда су тотивни (ТОТВø; напишем, пречитам, препатрим; срп. "написаћу", "прочитаћу", "nрегледаћу"). Од атотивних (одн. имперфективних) глагола може да се гради глаголски прилог садашњи (нпр. иедзащ̧и, ипивающи; срп. "седећи", "nевајућu"), а тотивни (одн. перфективни) глаголи могу да у реченици буду са прилогом цуалком (срп. "сасвим”) (Novakov, 1991: 74).

\section{ИСТРАЖИВАЧКИ КОРПУС}

Да би стекли одређену представу о фреквенцији типова видских парова, као и представу о појединачним видским паровима, определили смо се за анализу једног целовитог дела. Реч је о приручнику за учење енглеског и русинског језика Let's Speak English and Rusyn / Говоримо енглески и русински (Magoči, 1998). Публикација је првенствено конципирана за учење русинског језика за говорнике русинског језика на енглеском говорном подручју и представља резултат првог међународног русинистичког пројекта Говоримо русински. Прво издање приручника Бісідуйме по-руськы је забележило говор становника села Вишна Јаблонка у североисточној Словачкој, а друго, Говорім по-руськы, забележило је говор становника села Пидхирне у западној Украјини. Прво издање је објављено 1976. године, а друго 1979. године.

Сматрали смо да треће издање, Let's Speak English and Rusyn / Говоримо енглески и русински (Magoči, 1998), које бележи језик војвођанских Русина, својим садржајем омогућава формирање одговарајућег истраживачког корпуса. Приручник чине 25 поглавља. Свако поглавље је састављено од одређеног броја исказа на дату тему. Приручник укључује речи и изразе из 
свакодневних ситуација (у школи, ресторану, пошти, на путовању итд.) па се може очекивати да обухвата и најфреквентније глаголе, односно видске парове.

Пошто је пројекат Говоримо русински дао значајан допринос русинско-енглеској контрастивистици (Fejsa, 2006: 240) определили смо се да русинске видске парове из приручника не само наведемо него да их и преведемо на српски језик како би дали и одређени допринос русинскосрпској компаративистици. Верујемо да ће на тај начин категорија глаголског вида у русинском језику бити приближена, пре свега, заинтересованим студентима русинског језика, којима је српски језик матерњи а русински језик су изабрали у току студија на Филозофском факултету као изборни.

\section{ВИДСКИ ПАРОВИ}

У овом поглављу представљамо видске парове које смо успоставили на основу Let's Speak English and Rusyn / Говоримо енглески и русински.

Видски парови су унети по азбучном реду атотивних глагола видских парова. Тиме што прво наводимо атотивне, а затим тотивне глаголе не желимо сугерисати редослед настанка.

Италиком смо обележили онај тип видских парова чији су тотивни чланови настали на најуочљивији начин - додавањем одређеног префикса на облик атотивних чланова видских парова.

бешедовац, побешедовач : причати, попричати

бежац (бежиц), побегнуц : трчати, потрчати

биц, вдериц : тући, ударити

бии, побиц : тући, истући

бочкац, побочкащ; љубити, пољубити

брац, вжац : узимати, узети

бритовач ше, забритовац ше : бринути се, забринути се

будоваи, збудовач : градити, изградити

вези, превезц : возити, превести

вези, привези : возити, довести

вези, одвези : возити, одвести

веси, привеси: водити, довести

веси, одвеси: водити, одвести

вечерац, навечерац ше : вечерати, навечерати се

винчовач, повинчовач: честитати, почеститати

вихасновйовац, вихасновац : искоришћавати, искористити 
виходзиц, висц : излазити, изаћи

вишац, обешиц : качити, окачити; вешати, обесити

вищац, повищац : качити, покачити

влапац, влапиц : хватати, ухватити

водзиц, одвесц : водити, одвести

вожиц, одвезц : возити, одвести

волац, поволац : звати, позвати

врацац, врациц : враћати, вратити

врацац ше, врациц ше : враћати се, вратити се

вреи, зовреи : кључати, прокључати

врещзац (врещчи), зврещцац (зврещци) : вриштати, вриснути

глєдац, поглєдащ: тражити, потражити

гнац (гонї), одогнац (одгнац) : терати, отерати

готовиц, приготовиц : припремати, припремити

граи, одграи : свирати, одсвирати

губиц, погубии : кварити, покварити

гуториц, погуториц (повесц, гвариц): говорити, рећи (казати)

трабац, зграбац : грабити : зграбити

дихац, удихнуц : дисати, удахнути

дознавац, дознац : дознавати, дознати

допивац, допиц : досађивати, досадити

дорушовац, дорушиц : додиривати, додирнути

доставац, достац : добијати, добити

дотикац, дотхнуц : дотицати, дотаћи (дотакнути)

дpanau, nодpanau : гребати, огребати

дриляц, дрилїц : гурати, гурнути

дрец ше, роздрец ше : дерати се, раздерати се

думаи, подумач : мислити, помислити

єднац ше, поєднац ше : погађати се (ценкати се), погодити се

$\epsilon с$, поєси : јести, појести

жадац, пожадаи : желети, пожелети

жаловац, пожаловац : жалити, зажалити

жиц, пожиц : живети, поживети

жичац, пожичиц : зајмити, позајмити

жувац, пожувац : жвакати, сажвакати

забавяц ше, забавиц ше : забавити се, забављати се

заберац, завжац : заузимати, заузети

забивац, забиц : убијати, убити; укуцавати, укуцати (ексер) 
забувац, забуц : заборављати, заборавити

заверац, заврец : затварати, затворити

закончовац, закончиц : завршавати, завршити

заметац, замесц (позаметац) : мести (чистити), помести (почистити)

заперац, запрец : затварати, затворити

застановйовац (становяц), застановиц; заустављати, зауставити

зберац, позберац : скупљати, скупити

збувац ше, збуц ше : збивати се, збити се; дешавати се, десити се

здобувац, здобуц : стицати, стећи

здогадовац ше, здогаднуц ше : сећати се, сетити се

знац, дознац : знати, дознати

знємирйовац, знємириц : узнемиравати, узнемирити

знїщовац (нїщиц), знїщиц : уништавати, уништити

зошивац, зошиц : сашивати, сашити

иси, пойси : ићи, отићи

капац, скапац : нестајати, нестати

карац, покарац : кажњавати, казнити

кармиц, накармиц : хранити, нахранити

кашляц (кашлї), закашляц (закашлїц) ше : кашљати, закашљати се кивац, закивацฺ: њихати, зањихати

кихац, кихнуц : кијати, кинути

класц, положиц : стављати, ставити

копац, викопац : копати, ископати

краднуц, украднуц : красти, украсти

критиковач, викритиковац : критиковати, искритиковати

кричаu (кричищ), скричач (скричиц) : викати, викнути

круцчии (закруц̧ац, закруцьоващ), закруцици : завртати, заврнути

круцици, скруцииц : скретати, скренути

куповац, купиц : куповати, купити

куриц, покуриц : пушити, испушити (цигарету)

кусац, покусац (укушиц) : гристи, угристи (ујести)

ламац, зламац : ломити, сломити

ламац, поламац : ломити, поломити

лєгац, лєгнуц : легати, лећи (легнути)

лїгац, прелїгнуц (лїгнуц) : гутати, прогутати (гутнути)

любиц, полюбиц : волети, заволети

лярмац, злярмац : викати, викнути

мальовац, намальовац : сликати, насликати 
махац, махнуц : махати, махнути

мержиц, замержиц : мрзети, замрзети

модлїи, замодлїи : молити, замолити

модлїи, вимодлїи : молити, измолити

навиковац ше, навикнуц ше : навикавати се, навићи се (навикнути се)

наганяц (гнац), нагнац : терати, натерати

напущовац, напущиц : напуштати, напустити

находзиц, найсц : налазити, наћи

нєсподзивйовац, нєсподзивац : изненађивати, изненадити

нєставац, нєстац : нестајати, нестати

обачовац, обачиц : примећивати, приметити

обецовац, обецац : обећавати, обећати

обманьовац, обмануц : обмањивати, обманути

обрацац, обрациц : окретати, окренути

обходзиц, обисц : обилазити, обићи

одвитовац, одповесц : одговарати, одговорити

одводзиц, одвесц : одводити, одвести

одвожиц, одвезц : одвозити, одвести

означовац, означиц : означавати, означити

одказовац, одказац : отказивати, отказати

одпочивац, одпочинуц : одмарати, одморити

одходзиц, пойсц : одлазити, отићи

опадовац, опаднуц : опадати, опасти

оправяц, оправиц : оправљати, оправити

освойовац, освоїц : освајати, освојити

оставац, остац : остајати, остати

отверац, отвориц : отварати, отворити

охабяц, охабиц : остављати, оставити

ошмиховац ше (шмишкац ше), ошмихнуц ше : осмехивати се

(смешкати се), осмехнути се

падац, спаднуц : падати, пасти

паметаu, запаметац : памтити, запамтити

nасовац, напасовац : пасовати, напасовати

nатриц, nопатриц : гледати, погледати

пачиц ше, попачиц ше : свиђати се, свидети се

nисац, написаи : писати, написати

nuтаu, запитац: тражити, затражити

питац ше, опитац ше : питати, упитати 
nuu, nопиц : пити, попити

плївац, преплївац : пливати, препливати

победзовац, победзиц : побеђивати, победити

поволовац, поволац : позивати, позвати

подписовац, подписац : потписивати, потписати

подписовац ше, подписац ше : потписивати се, потписати се

полудньовац, наполудньовац ше : ручати, наручати се

помагац, помочи (помогнуц) : помагати, помоћи

помивац, помиц (попомивац) : прати, опрати (судове)

понагляц, попонагляц : журити, пожурити

поносовац ще, попоносовац ще : жалити се, пожалити се

поспишовац ше, поспишиц ше : успевати, успети

поставац, постац: постајати, постати

потрафяц, потрафиц : погађати, погодити

похопйовац, похопиц : схватати, схватити

поцаговац, поцагнуц : повлачити, повући

починац, почац : почињати, почети

пояшньовац, пояшнїц : објашњавати, објаснити

правиц, направиц : правити, направити

превезц, превожиц : превести, превозити

предавац, предац : продавати, продати

предлужовац, предлужиц : продужавати, продужити

пренаходзиц, пренайсц : проналазити, пронаћи

преношиц, пренєсц : преносити, пренети

пресовац, випресовац : пресовати, испресовати

преставац, престац : престајати, престати

преходзиц, прейсц : пролазити, проћи

прешвечовац, прешвечиц : уверавати, уверити

приблїжовац ше, приблїжиц ше : приближавати се, приближити се привиковац ше (привикац ше), привикнуц ше : навикавати се, навићи се (навикнути се)

приводзиц, привесц : доводити, довести

привожиц, привезц : довозити, довести

придавац, придац : предавати, предати

придавац ше, придац ше : предавати се, предати се

примушовац, примушиц : приморавати, приморати

приношиц (нєсц, ношиц), принєсц : доносити (носити), донети

припадац, припаднуц : припадати, припасти 
приповедаи, виприповедач : причати, испричати

приставац, пристац : пристајати, пристати

приходзиц, присц : долазити, доћи

прицискац, прициснуц : притискати, притиснути

пробовац, попробовач (спробовац) : пробати, испробати

райбаи, вирайбаи : прати, опрати (веш)

резац, порезац : сећи, исећи

puхтац, порихтац : спремати, спремити

рихтай ше, порихтац ше : спремати се, спремити се

ришовац, ришиц : решавати, решити

робиц, зробич : радити, урадити

розбивац, розбиц : разбијати, разбити

роздумовац, роздумац : размишљати, размислити

розмазовац, розмазац : мазити, размазити

розпатрац, розпатриц : разгледавати, разгледати

розумиц, порозумиц (зрозумиц) : разумевати, разумети; схватати,

схватити

роснуц, вироснуц : расти, израсти

руковац ше, поруковац ше : руковати се, поруковати се

руцац, руциц : бацати, бацити

рушац, рушиц : дирати, дирнути; кретати, кренути

секирац ше, насекирац ше : секирати се, насекирати се

слухац, послухац : слушати, послушати

случовац ше, случиц ше : дешавати се, десити се

скакац, скочиц : скакати, скочити

складац, зложиц : слагати, сложити

складац ше, зложиц ше : слагати се, сложити се

сообщовац, сообщиц : саопштавати, саопштити

cnau, засnаu : спавати, заспати

спреведац, спревесц : варати, преварити

ставац, стануц : устајати, устати

ставац ше, стац ше : дешавати се, десити се

cmapau ше, застарац ше: бринути се, забринути се

старац ше, постарац ше : старати се, постарати се

стац, постац : стајати, постајати

страшиц, настрашиц : плашити, заплашити

стретац, стретнуц : сретати, срести

стретац ше, стретнуц ше : сретати се, срести се 
сходзиц ше, зисц ше : састајати се, састати се

сцекац, сцекнуц : бежати, побећи

сцец, зосцец : хтети; желети, пожелети

сциговац, сцигнуц : стизати, стићи

сцискац, сциснуц : стискати, стиснути; стезати, стегнути

твориц (стваряц), створиц : стварати, створити

толковац, потолковач : тумачити, растумачити

mpanuu ше, натрапиц ше : мучити се, намучити се

тращчuи, стращчиu : губити, изгубити

трациич ше, стращчиц ше : губити се, изгубити се

треси, витреси : трести, истрести

тримац, затримач : држати, задржати удавац ше, удац ше : успевати, успети

указовац, указац : показивати, показати

указовац ше, указац ше : показивати се, показати се

умерац, умрец : умирати, умрети

умивац, умиц : умивати, умити

умивац ше, умиц ше : умивати се, умити се

упознавац ше, упознац ше : упознавати се, упознати се

упрепасцовац, упрепасциц : упропашћавати, упропастити

утвердзовац, утвердзиц : утврђивати, утврдити

уходзиц, войсц : улазити, ући

учиц ше, научиц ше : учити се, научити се

фарбии, офарбии : фарбати, офарбати

фриштиковаи, нафриштиковач ше : доручковати, надоручковати се

хасновац, похасновач : користити, искористити

ходзиц, преходзии : ходати, проходати

цагац, поцагнуц : вући, повући

цеерпиц, прецерпии : трпети, претрпети

цุитанй, сиитанйи : лагати, слагати

цุиловац, почиловац : љубити, пољубити

чекаи, причекац : чекати, сачекати

читац, пречитац : читати, прочитати

чувствовач, почувствовач : осећати, осетити

чудовац ше, зачудовач ше : чудити се, зачудити се

чуи, зачуи : чути, зачути

шедаи, пошедаи : седати, поседати

шедзии, пошедзии : седети, поседети 
шедац, шеднуц : седати, сести

шейтаu ше, прешейтаų ше : шетати се, прошетати се

шептац, шепнуц : шаптати, шапнути

menmau, noшеnmaus : шапутати, пошапутати (шапнути)

ииц, зошиц : шити, сашити

шкрабаи, пошкрабаи : гребати, огребати; чешати, почешати

шмеяи ше, зашмеяц ше : смејати се, засмејати се

шпивац, зашпивац : певати, запевати

шпуряц, шпуриц : бацати, бацити

щезовац, щезнуц : ишчезавати, ишчезнути

щипац, ущипнуц : штипати, уштинути

явяц, явиц : јављати, јавити

\section{АНАЛИЗА ИСТРАЖИВАЧКОГ КОРПУСА}

Истраживачки корпус чине 255 видских парова. Скоро половина, тачније 118 видских парова (в. парове обележене курзивом), настали су префиксацијом. Од 14 префикса најчешћи је префикс по-, који се појављује чак 46 пута (нпр. чувствовац, почувствовац). Префикси за- и на- се јављају 14 пута (нпр. шпивац, зашпиващз; учиu, научиu). Префикси c-, з- и ви- по 7 пута (нпр. круции, скруциц; будовац, збудоващ; копац, викопац), а префикс пре- 6 пута (нпр. вези, превези). Префикси при- и од- се јављају 4 пута (нпр. весц, привеси; граи, одграч), а префикси зо- и о- по 3 пута (нпр. врец, зоврец; фарбиц, офарбии). Префикси y-, роз- и до- су забележени само једном (нпр. краднуц, украднуи; дрец ше, роздрец ше; знац, дознащ). Ови видски парови, њих 118, одликују се тиме што у њима тотивни члан видског пара настаје додавањем одређеног префикса на непромењени облик атотивног члана видског пара.

Наведени префикси се, међутим, у многим случајевима за формирање видских парова користе заједно са суфиксима. Тако нпр. у видском пару щ̧ипаu, ущзипнуц тотивни члан видског пара формира се, поред префикса $y$-, и са суфиксом -ну-. На сличан начин формирани су нпр. и: дихац, удихнуц; жсичац, пожччищ; становяц, застановищ; лӥтац, прелї̈нуц; цуагац, поцагнуц.

У видском пару бежац, побегнуц тотивни глагол побегнуц формира се комбиновањем префикса по-, суфикса -ну и наслеђене гласовне промене сугласника 2 (од прасловенског $g$ ). Наслеђене гласовне промене у корену глагола очитавају се и у видском пару скакаи, скочии. Истраживачки корпус указује на десетак видских парова чији је настанак условљен историјским гласовним променама. 
У корпусу бележимо 17 видских парова који су формирани на основу алтернирања самогласника, тј. суфикса $-a$ (или $я<j a)$ и суфикса $-u$ (нпр. рушаи, рушищ; розпатраи, розпатрищ; явяи, явищ; шпуряи, шпурищ).

Значајан је број видских парова типа поволоваи, поволач и подписоваи, nодписаи у којима су оба члана видског пара префиксована (у овим примерима са no- и под-), а атотивни члан видског пара карактерише суфикс -ов(a). У зависности од самогласника основе атотивни глагол добија и суфиксе - $а в(a)$ (нпр. дознаваи, дознаи; доставаи, достаи), -(и)ва (нпр. допиваи, допич; зошиваи, зошич) и -(у)ва (нпр. забуваи, забуц; збувач ше, збуи ше). Атотивних глагола са суфиксом -ов(a) у корпусу има 32 , са - $а в(a) 14$, са -(u)ва 8 и са $-(y)$ ва 3. У видским паровима ови суфикси најчешће алтернирају са суфиксима $-u$ и - $a$ тотивних глагола. Тотивни члан видског пара је са суфиксом - $и$ у корпусу формиран 26 пута (нпр. куповаи, купи; закруцоваи, закруцич; умиваи ше, умии ше), а са суфиксом а- 22 пута (нпр. одказоваи, одказаи; указоваи, указаи; придаваи, придаи). Поред ове две алтернације, суфикси -ова / -ава / -ива алтернирају и са суфиксом -ну и то у 9 видска пара (нпр. сциговаи, сцигнуй; ошмиховач ше, ошмихнуц ше).

Суфикс -ну још чешће, тачније 16 пута, алтернира са суфиксом - $а$ (нпр. махаи, махнуц; лєгаи, лєгнуи; припадаи, припаднуи). Глаголи са суфиксом -ну у корпусу 27 пута формирају тотивни члан видског пара.

У корпусу се истиче и алтернација суфикса $a$ - и $u$, која је забележена 14 пута (нпр. влапаи, влапищ; розпатраи, розпатриц; руцаи, руции). Глаголи са суфиксом - $a$ чине атотивни, а глаголи са суфиксом -u чине тотовни члан видског пара.

30 видских парова нису формирани изменом суфикса него изменом глаголске основе. У русинистици је издвојено само пет видских парова са суплетивном основом (Ramač, 2002: 116) од којих је наш корпус обухватио гутории - повеси, класи - положии, као и варијанте забераи - завжаи, находзии - найси и пренаходзиц - пренайси, што значи да само видски пар баи ше злєкнуи ше није укључен у наш корпус. Корпус је, међутим, указао на значајан број других видских парова са суплетивном основом. Поред бич - вдерии и складаи ше - зложии ше истичу се видски парови који укључују глаголе кретања. Већина њих укључује глаголе кретања иси, ходзии, вези, вожии, веси и водзиц. Наведени глаголи се не разликују у видском модалитету јер су сви атотивни, али се разликују у акционсарту. Наиме иси, вези, веси су једносмерни и једнократни, а ходзии, водзиц и вожиц су вишесмерни и вишекратни. Видски парови се формирају префиксацијом тако што само једнократни глаголи прелазе у тотивне глаголе (нпр. иси, наиси; веси, одвеси; вези, привези). 
Сагледавајући префиксоване видске парове, Рамач је приметио да неки глаголи кретања представљају изузетак јер и префиксовани задржавају, у његовој терминологији, несвршени вид. Као примере навео је глаголе ходзии (преходзии, уходзии, одходзии, заходзич) и вожиц (превожии, завожии, довожии, одвожии, навожии, привожси), али није навео разлог зашто су изузетак. Ми разлог видимо у томе што значења која карактеришу тзв. неодређено-моторне глаголе ("вишесмерност", "вишекратност" и "неодређеност") онемогућавају целовито сагледавање глаголских реализација. Наш корпус је, међутим, потврдио да и један изузетак. Док је глагол преходзии у значењу "пролазити" атотиван, глагол преходзии у значењу "проходати" је тотиван пошто омогућава целовито сагледавање дотичне глаголске ситуације; иначе, два лексикографска дела Одсека за русинистику нису забележила глагол преходзии у значењу "проходати" (углавном о детету) (Ramač, 1995-1997; Ramač, 2010), што може указивати на новије порекло, односно утицај српског језика. И најфреквентнији префикс у корпусу, префикс по-, такође може са атотивним, вишекратним глаголима кретања формирати тотивне глаголе (нпр. походзич - мало ходати, поношиц - мало носати/носити и поводзии - мало водати / водити; Fejsa, 2005a: 235). До тога долази зато што реализације ситуација које се преносе изведеним глаголима са префиксом по- имају ограничено трајање, па их је због тога могуће целовито сагледати. Двадесетак је видских парова у нашем корпусу који су формирани изменом глаголске основе код глагола кретања, нпр. виходзиц - виси, водзии - одвеси, вожии - одвези, одходзии - пойси итд. Поред наведених, на овај начин настали су и примери бежаи (бежии) - побегнуи и гнаи (гонй) - одогнаи (одгнаи).

\section{ЗАКЉУЧАК}

У русинистици до сада није посвећивана значајнија пажња видским паровима. У раду су установљена 255 видска пара, којима су обезбеђени и преводни еквиваленти у српском језику.

Скоро половина парова, тачније 118 видских парова, одликују се тиме што је у њима тотивни члан видског пара настао додавањем одређеног префикса на облик атотивног члана видског пара, који остаје непромењен. Најчешћи префикси употребљени за формирање тотивног члана видског пара су по-, за- и -на.

Најчешће употребљени суфикси за формирање атотивних глагола су суфикс -ов(a), суфикс - $а$, суфикс -ав(a), суфикс -(u)ва и суфикс -(y)ва. Најчешће 
употребљени суфикси за формирање тотивних глагола су суфикс $-н y$, суфикс $-u$ и суфикс $a$-.

Многи видски парови су настали комбиновањем префиксације и суфиксације (нпр. жсчац - пожсичич; становяц - застановиц; лїтац - прелї̈нуц; цุагаи - почуагнуи).

Посебна пажња је посвећена видским паровима којима је основа различита. Поред пет видских парова са суплетивним основама (нпр. брац вжац), који су досад забележени у русинистици, наш истраживачки корпус је указао на још двадесетак видских парова који су формирани изменом глаголске основе. То се односи на једнократне глаголе (нпр. виходзиц - виси). У већини случајева префиксација вишекратних глагола не утиче на измену атотивног модалитета што, међутим, није случај са префисацијом префиксом по- (нпр. ношиц - поношич) и, у одређеном значењу, са префиксом пре-.

Овај рад, између осталог, пружа увид у фреквенцију језичких појава везаних за граматичку категорију вида и представља најчешће видске парове у русинском језику. Сматрамо да ће његови резултати имати и практичну примену у настави русинског језика као изборног.

Mihajlo P. Fejsa

ASPECTUAL PAIRS IN THE RUTHENIAN LANGUAGE

\section{Summary}

Aspectual pairs have not been given attention up to this point in the Ruthenian linguistics. The paper provides a list of 255 aspectual pairs that have been translated into the Serbian language.

The author have tried to point out the most frequent models of forming aspectual pairs in Ruthenian. Almost half of the aspectual pairs are generated by prefixation, and the most common prefixes are no-, за- and - $\mathrm{Ha}$. In this case the unprefixed verb represents the nontotive member of the aspectual pair and the prefixed verb represents the totive member of the aspectual pair. Many aspectual pairs are formed by combining prefixation with suffixation. The most commonly used suffixes are -ова and $-н y$. Suffix -ова is characteristic of the non-totive verbs and the suffix $-\mu y$ is characteristic of the totive ones.

Special attention has been paid to the aspectual pairs where the bases of the verbs differ (for ех. виходзии - виси, водзии - одвеси, вожиц - одвези, одходзии - пойси еtс.). All verbs of motion are non-totive but only the verbs conveying situations that occur once are capable of forming the totive member of the aspectual pair.

Keywords: Ruthenian language, verbal aspect, aspectual pairs, prefixation, suffixation, verbs of motion. 


\section{LITERATURA}

Avilova, N. S. (1976). Vid glagola i semantika glagol'nogo slova. Moskva: Nauka. (Knjiga štampana ćirilicom.)

Bondarko, A. V. (1971). Vid i vremja russkogo glagola: Značenije i upotrebljenije. Moskva: Prosveščenije. (Knjiga štampana ćirilicom.)

Comrie, B. (1991). Aspect: An Introduction to the Study of Verbal Aspect and Related Problems. Cambridge: Cambridge University Press.

Fejsa, M. (2005a). Vreme $i$ vid u rusinskom i engleskom jeziku. Novi Sad: IK Prometej i Univerzitet u Novom Sadu - Filozofski fakultet - Odsek za rusinski jezik i književnost. (Knjiga štampana ćirilicom.)

Fejsa, M. (2005b). Semantični zmisti kategorijoh vida i akcionsarta u ruskim i anglijskim jaziku. Švetlosc, 3, 323-360. (Rad štampan ćirilicom.)

Fejsa, M. (2006). Rusko-anglijska kontrastivistika. U: Fejsa, M. (ured.) (2006) Rusini/Rusnaci/ Ruthenians (1745-2005) I. Novi Sad: Filozofski fakultet Odsek za rusinistiku, IK Prometej i KPD DOK, 239-247. (Rad štampan ćirilicom.)

Fejsa, M. (2009). Funkcionovanje konstrukcijifformi Vø u prenošenju časo-vidovih odnošen 'oh u pripovedkoh Havrijila Kostel'nika. Novi Sad: IK Prometej i Filozofski fakultet - Oddzeljenje za rusinistiku. (ćir.) (Knjiga štampana ćirilicom.)

Fejsa, M. (2017). Pravopisni slovnjik ruskoho jazika. Preuzeto sa http://digitalna.ff.uns.ac.rs/sadrzaj/2017/978-86-6065-419-1 (Rad štampan ćirilicom.)

Isačenko, A. V. (1960). Grammatičeskij stroj russkogo jazyka v sopostavleniji s slovackim: Morfologija II, Bratislava: Izdatel'stvo Slovackoj akademiji nauk. (Knjiga štampana ćirilicom.)

Kočiš, M. M. (1971). Pravopis ruskoho jazika. Novi Sad: Pokrajinski zavod za vidavanje učebnjikoh. (Knjiga štampana ćirilicom.)

Kočiš, M. M. (1977). Gramatika ruskoho jazika: Fonetika-morfologija-leksika I. Novi Sad: Pokrajinski zavod za vidavanje učebnjikoh. (Knjiga štampana ćirilicom.)

Kočiš, M. M. (1978). Lingvistični roboti. Novi Sad: Ruske slovo. (Knjiga štampana ćirilicom.)

Kostel`nik, G. (1975). Proza. Novi Sad: Ruske slovo. (Knjiga štampana ćirilicom.) Magoči, P. R.-Fejsa, M. (1998). Bešedujme po anglijski i po ruski / Let ’s Speak English and Rusyn. Novi Sad: Ruske slovo. (Knjiga štampana ćirilicom.) 
Novakov, P. (1991). Glagolski vid $i$ akcionsart u engleskom i srpskohrvatskom jeziku (nepublikovana doktorska disertacija). Novi Sad: Univerzitet u Novom Sadu, Filozofski fakultet.

Ramač, Ju.-Fejsa, M. \& Medješi, H. (1995). Srpsko-rusinski rečnik / Serbsko-ruski slovnjik, I, A-Nj. Novi Sad: Univerzitet u Novim Sadze - Filozofski fakultet - Katedra za ruski jazik i literaturu i Družtvo za ruski jazik i literaturu. (Rečnik štampan ćirilicom.)

Ramač, Ju.-Fejsa, M. \& Medješi, H. (1997). Srpsko-rusinski rečnik / Serbsko-ruski slovnjik, II, O-Š. Beograd: Zavod za učebnjiki i nastavni sredstva, Univerzitet u Novim Sadze - Filozofski fakultet - Katedra za ruski jazik i literaturu i Družtvo za ruski jazik i literaturu. (Rečnik štampan ćirilicom.)

Ramač, Ju. (2002). Gramatika ruskoho jazika. Beograd: Zavod za udžbenike i nastavna sredstva. (Knjiga štampana ćirilicom.)

Ramač, Ju., Timko-Djitko, O., Medješi, H. i Fejsa, M. (2010). Rusko-serbski slovnjik / Rusinsko-srpski rečnik. Novi Sad: Univerzitet u Novom Sadze Filozofski fakultet - Katedra za ruski jazik i literaturu i Zavod za kulturu vojvodjanskih Rusnacoh. (Rečnik štampan ćirilicom.)

Vinogradov, V. V. (1972). Russkij jazyk. Moskva: Vysšaja škola. (Knjiga štampana ćirilicom.) 